\title{
Comparison of gut microbiome between low fiber and high fat diet fed mice
}

\author{
Nakwon Hwang ${ }^{1}$ (D) Taekil Eom² ${ }^{2}$ (D) Tatsuya Unno ${ }^{1}$ \\ 저식이섬유 및 고지방 사료 급여 마우스의 장내 미생물 생태 변화
}

황낙원 ${ }^{1} \cdot$ 엄태길 ${ }^{2} \cdot$ 운노타쯔야 ${ }^{1}$

Received: 2 February 2018 / Accepted: 3 May 2018 / Published Online: 30 June 2018

(C) The Korean Society for Applied Biological Chemistry 2018

\begin{abstract}
Due to the recent economic development, the diet style has become more and more westernized in Korea, which increased the concern of our well-beings. Our well-beings are also associated with the gut microbiota which vary depending on the dietary intake. In this study, we compared gut microbiome shifted by two diets: high-fat diets (HFD) and low-fiber diet (LFD) based on 16S rRNA gene sequences using MiSeq. Compared to the control diet, LFD and HFD treatments significantly decreased species richness, while there was no difference in species evenness. Both diet treatments significantly increased the relative abundance of the Proteobacteria $(p<0.05)$, especially the genus Sutterella. Bacteroidetes was significantly decreased in HFD groups, where the family S24-7 was decreased most. On the other hand, significant difference between HFD and LFD was seen among Firmicutes, where the abundance of family Lachnospiraceae was lower in LFD groups $(p<0.05)$. PICRUSt-based metabolic difference analyses showed LFD treatment significantly decreased metabolisms of amino acid, carbohydrate and methane $(p<0.01)$. In contrast, HFD significantly increased amino acid metabolism $(p<0.05)$.
\end{abstract}

Tatsuya Unno $(\square)$

E-mail: tatsu@jejunu.ac.kr

${ }^{1}$ Faculty of Biotechnology, School of Life Sciences, SARI, Jeju National University, Jeju 63243, Republic of Korea

${ }^{2}$ Subtropical/tropical Organism Gene Bank, Jeju National University, Jeju 63243, Republic of Korea

This is an Open Access article distributed under the terms of the Creative Commons Attribution Non-Commercial License (http://creativecommons. org/licenses/by-nc/3.0/) which permits unrestricted non-commercial use, distribution, and reproduction in any medium, provided the original work is properly cited.
Glycan biosynthesis and metabolism were significantly increased in both treatment groups $(p<0.01)$. Our results suggest that longterm unbalanced dietary intakes induce gut dysbiosis, leading to metabolic and colonic disorders.

Keywords Gut microbiome $\cdot$ High-fat diet $\cdot$ Low-fiber diet

\section{서 론}

경제 성장으로 인하여 현재사회의 식생활 습관이 서구화 되어 짐에 따라 식이 섬유가 풍부한 곡물 및 채소류의 섭취는 줄어 들면서, 지방이 풍부한 육류위주의 식습관으로 바뀌어가고 있다. 또한 식품 가공기술의 발전으로 인하여 지방이 많이 함유되어 있는 인스턴트식품에 대한 소비가 늘어나고 있다[1,2]. 이러한 저식이섬유, 고지방 식단에 의해서 체내에서 지방이 축적됨에 따라 비만[3], 2형 당뇨병[4], 고혈압[5]의 발병률이 높아지고 있 고, 심혈관계질환[6] 등과 같은 다양한 대사성 질환[7]까지 초 래할 수 있다. 이러한 대사성 질환들은 동맥 경화증과 같은 다 양한 심혈관계질환[8], 대장암을 비롯한 다양한 암의 발생[9], 염 증성 장 질환[10] 등과 다양한 질병에 대한 원인으로 지목되고 있다.

사람을 비롯한 다양한 포유동물들 장내에는 약 2,000 여종의 $10^{14}-10^{15}$ 개 이상의 공생 세균이 존재한다[11]. 지금까지 이들 장 내 미생물 군집에 대한 연구는 다양한 질환을 일으키는 병원 미생물에 대한 연구에 국한되었으나, 최근 들어 분자생물학적 기술의 발전으로 인하여 이들 미생물들의 인체에 대한 역할에 대해서 연구가 활발히 진행되고 있다[12]. 지금까지 이들 장내 미생물들은 신체 에너지 대사과정 조절[13], 인체 면역 반응 조 절[14]에 있어서 중요한 역할을 한다고 연구되어 있다. 이러한 
장내 미생물 생태는 다양한 환경적인 요인과 식이 습관에 따라 그 구성이 복잡 다양하게 변화하며, 이러한 장내 미생물 생태 구성이 불균형적으로 변화하는 것을 디스바이오시스(dysbiosys) 라고 하며, 이러한 dysbiosys에 의해서 염증성 장질환, 대장암, 비만 및 당뇨 등과 같은 다양한 만성질환의 원인이 되기도 한 다[15].

특히, 식이 습관은 인체 장내 미생물 생태와 밀접한 연관이 있으며, 섭취된 음식물들의 대부분은 소화 과정을 거치면서 소 장에서 흡수되어지나, 소장에서 흡수되지 못하는 식이섬유 및 복합 다당류는 대장 내에서 다양한 장내 미생물이 이용하여 에 너지원으로 사용한다[16]. 또한 과량의 섭취된 지방은 장내 미 생물 군집들을 변화시켜서 장내에서 발현이 되는 지방단백질분 해효소(Lipoprotetein lipase)를 효소를 발현시키거나[17], 장내 미 생물이 생산하는 지방산의 한 종류인 아세테이트(acetate)가 지 방세포안의 지방 축적을 유도하여 비만을 유도하기도 한다고 연 구되어져 있다[18].

그러나, 이러한 식이섬유 제한 및 고지방 식이 섭취 시 전체 적인 장내 미생물 변화에 대한 분석은 미비한 편이다. 이에 본 연구에서는 실험동물을 대상으로 각각 저식이섬유와 고지방 식 이를 공급하여 기본적으로 생리활성데이터를 비교하였고, 장내 미생물 생태의 변화와 추정적 대사 변화를 추측하기 위해 $16 \mathrm{~S}$ rRNA유전자 기반으로 하여 문(Phylum) 및 속(Genus) 수준에서 분석하였으며, 이를 식이 변화에 따른 장내미생물생태 분석에 기초 자료로 제공하고자 한다.

\section{재료 및 방법}

\section{동물실험 디자인}

실험동물은 5주령 된 암컷 ICR 마우스를 (주)오리엔트바이오 (Korea)에서 구입하여, 7일간의 적응기를 거쳐 본 실험에 사용 하였다. 사육실 환경은 온도 $\left(22 \pm 2{ }^{\circ} \mathrm{C}\right)$, 습도 $(20-55 \%)$ 및 광주기 (명암 12시간 간격)가 조절되며, 모든 실험동물은 사료와 물을 자유 급식하였다. 일주일간의 적응기 후 실험동물은 그룹당 6 마리씩 총 3 그룹으로 구분하였다. 정상 대조군(CTL)은 일반 사 료(5L79, Lab Diet, St. Louis, USA)를 급여하였고, 고지방 사 료 처리군(HFD)은 $45 \%$ 지방이 함량된 사료(D12451, Research Diets, New Brunswick, USA)를 3주간 공급하였다. 저식이섬유 사료 처리군(LFD)은 $0.1 \%$ 식이섬유가 함유되게 제조하여 (DooYeol Biotech, Seoul, Korea)를 3주간 급여 하였으며 각

Table 1 The general composition of diets

\begin{tabular}{lccc}
\hline \hline \multirow{2}{*}{ Ingredients } & \multicolumn{3}{c}{ Contents (\%) } \\
\cline { 2 - 4 } & Normal diet & Low fiber diet & High fat diet \\
\hline Moisture & 8.1 & 9.0 & - \\
Crude protein & 18 & 21.9 & 24 \\
Crude fat & 5 & 6.1 & 24 \\
Crude fiber & 5 & 0.1 & 5.82 \\
Crude ash & 8 & 5.9 & - \\
NEE & 55.9 & 57.0 & 46.18 \\
\hline
\end{tabular}

NFE (nitrogen-free extract) fraction $\%=100$ (moisture $\%+$ crude ash $\%+$ crude fat $\%+$ crude protein $\%+$ dietary fiber $\%$ )
사료의 일반성분은 Table 1에 나타내었다. 실험동물 사육 기간 동안 물과 식이는 제한 없이 공급하였다. 본 실험은 제주대학 교 실험동물윤리위원회의 사전심의를 받아 진행하였다(ACUCJNU: 2016-0045).

\section{체중 및 식이음수 섭취량 측정}

체중 및 식이음수 섭취량은 전 실험기간 동안 주 1 회 측정하였 고, 실험동물을 한 마리씩 케이지에 수용하여 각각 실험동물 개 체별로 측정된 사료 및 물을 급여한 24시간 후 섭취잔량을 측 정하여 산출하였다.

\section{분변 채취 및 장내미생물생태분석}

실험동물의 분변은 실험동물 개체별로 수용된 케이지에 절식망 을 설치하여 5 시간 이내에 낙하된 분변을 채취한 뒤, $-80^{\circ} \mathrm{C}$ 에 서 보관하였다. 분변 미생물 $\mathrm{DNA}$ 는 PowerFecal DNA isolation kit (MOBIO Laboratories Inc., Germantown, USA) 를 이용하여 추출하였다. 추출된 DNA는 $16 \mathrm{~S}$ rRNA 유전자의 V4 부분을 증폭시킨 후 2-step PCR을 통해 Illumina MiSeq 플랫폼에 맞춰library를 제작하였고, 시퀀싱(sequencing)은 마크로 젠(Seoul, Korea)에서 수행하였다. 장내미생물생태는 MOTHUR 를 사용하여 전처리 및 분석하였다.

\section{통계분석}

통계학적 분석은 $\mathrm{ANOVA}$ 를 사용하여 유의성검정을 실시하였고, 유의성이 있을 때 사후검정으로 Tukey's HSD test를 사용하였 다 $(p<0.05)$. 그룹간의 비교는 Duncan's multiple range test를 실시하였으며, $p<0.05$ 일 때 유의성이 있는 것으로 판단하였다. 각 그룹간 미생물생태비교에서는 $\mathrm{AMOVA}$ 로 유의적 차이를 판 단하였고[19] Non-metric multidimensional scaling (NMDS) plot으 로 나타내었으며, genus 수준의 abundance 차이는 METASTATS [20]로 비교하였다. $16 \mathrm{~S}$ rRNA 유전자 기반 metabolic pathway 추정은 PICRUSt [21]를 이용하여 비교하였고, STAMP [22] v2.1.3를 사용하여 heatmap으로 나타내었다. 이는 ANOVA로 유 의성 검정을 실시하였고, 유의성이 있을 때 Tukey's HSD test 로 사후검정 하였다 $(p<0.01)$. 또한 이에 따른 계통수 분석은 The Unweighted Pair Group Method with Arithmetic Mean 방법을 사용하여 나타내었다.

\section{결과 및 고찰}

\section{그룹간 체중 변화량 및 식이, 음수 섭춰량}

각 그룹에 일반식이, 고지방 식이, 저식이섬유 식이를 3주간 급 여 후, 체중 변화량과 식이 및 음수 섭취량은 Table 2에 나타 내었다. 그룹별 체중 변화량에서 $\mathrm{CTL}$ 그룹은 $25.56 \pm 0.31 \mathrm{~g}$ 에서 $28.08 \pm 0.39 \mathrm{~g}$ 으로 증가하였으며 $(p<0.001), \mathrm{HFD}$ 그룹은 25.36 $0.35 \mathrm{~g}$ 에서 $27.15 \pm 0.37 \mathrm{~g}$ 으로 유의성 있게 증가 하였다 $(p<0.01)$. 반면 LFD그룹은 $25.64 \pm 0.35 \mathrm{~g}$ 에서 $26.46 \pm 0.51 \mathrm{~g}$ 으로 $0.81 \pm 0.47 \mathrm{~g}$ 증가하였으나, 유의적인 차이는 보이지 않았다. 식이 섭취 3 주 후 각 그룹간의 몸무게는 유의적인 차이를 나타내지 않았다. 개 체 별 하루 식이 섭취량은 CTL 그룹이 $6.76 \pm 0.49 \mathrm{~g}$ 으로 가장 많은 양의 사료를 섭취하였으나, LFD 그룹은 $5.15 \pm 0.33 \mathrm{~g}$, 
Table 2 Body weight, intake of food and water in each mouse

\begin{tabular}{|c|c|c|c|c|}
\hline \multirow{2}{*}{\multicolumn{2}{|c|}{ Bioparameters }} & \multicolumn{3}{|c|}{ Treatments } \\
\hline & & CTL & LFD & HFD \\
\hline \multirow{2}{*}{$\begin{array}{l}\text { Body weight } \\
\text { (g) }\end{array}$} & Initial & $25.56 \pm 0.31$ & $25.64 \pm 0.35$ & $25.36 \pm 0.35$ \\
\hline & Final & $28.08 \pm 0.39 * *$ & $26.46 \pm 0.51$ & $27.15 \pm 0.37 *$ \\
\hline \multicolumn{2}{|c|}{ Food intake (g) } & $6.76 \pm 0.49$ & $5.15 \pm 0.33^{\$}$ & $3.87 \pm 0.33^{\$ \$}$ \\
\hline \multicolumn{2}{|c|}{ Water intake (mL) } & $7.75 \pm 0.28$ & $7.54 \pm 0.44$ & $6.01 \pm 0.65$ \\
\hline
\end{tabular}

The data are shown as the mean $\pm \operatorname{SEM}(n=6)$

${ }^{*} p<0.01,{ }^{* *} p<0.001$ vs initial in each treatment and ${ }^{\$} p<0.05,{ }^{\$} p<0.001$ vs Normal diet in Tukey's HSD test

$\mathrm{HFD}$ 그룹은 $3.87 \pm 0.33 \mathrm{~g}$ 으로 $\mathrm{CTL}$ 그룹에 비하여 식이 섭취량 이 유의적으로 감소함을 나타내었다.

\section{장내미생물생태 비교}

장내미생물생태 비교를 위해서 분변으로부터 얻어진 DNA로부 터 전처리를 후 가장 작은 염기서열 개수인 25763개에 맞추어 모든 데이터를 재표집화 시켰으며, 총 2165개의 operational taxonomic units (OTUs)를 확보하여 분석하였다. 종 다양성 지 수는 Chao index와 Shannon index를 비교하였으며 Fig. 1에 나타내었다. Chao index는 종 풍부도를 비교하는 것으로[23], $\mathrm{HFD}$ 그룹 및 $\mathrm{LFD}$ 그룹이 CTL보다 유의적으로 낮은 장내 미 생물 군집을 가지는 것으로 볼 수 있다. 이는 고지방 식이와 저 식이섬유 식이로 인해 장내 미생물 종 군집의 종류가 적어지는 것으로 사료된다. 반면 종 균등도를 나타내는 Shannon index [23]에서는 CTL 그룹 및 $\mathrm{HFD}, \mathrm{LFD}$ 그룹간에 유의적인 차이 를 나타내지 않았고, 이는 고지방 및 저식이섬유 식이로 인해 장내 미생물 균등도가 영향을 받지 않는 것으로 사료된다. 희 박화 곡선(rarefaction curve)은 염기서열 수와 OTUs 수의 관계 를 나타내는데 OTUs가 많고 염기서열수가 많을수록 장내 미생 물군집의 다양성이 높음을 나타낸다. LFD 그룹과 HFD 그룹의 희박화 곡선이 비슷하며, CTL그룹에 비하여 빨리 수렴하는 것 으로 보아 $\mathrm{LFD}$ 그룹과 $\mathrm{HFD}$ 그룹의 장내 미생물 군집이 $\mathrm{CTL}$ 그룹보다 다양하지 않는 것을 나타낸다.

거시적인 장내미생물 생태는 계통수(phylogenic tree)와
$\mathrm{NMDS}$ 를 사용하여 비교하였다(Fig. 2). 개체별로 이루어진 계통 수 비교에서는 크게 군집I과 II로 나뉘었으며, 군집 I은 CTL그 룹으로 나타났고, 군집 II는 $\mathrm{LFD}$ 그룹과 $\mathrm{HFD}$ 그룹으로 나타났다. 이는 $\mathrm{LFD}$ 그룹과 $\mathrm{HFD}$ 그룹이 $\mathrm{CTL}$ 그룹의 장내 미생물 생태가 확연히 다름을 나타낸다. 또한 군집 II는 다시 두 군집 i와 ii로 나타나는데, 이는 각각 $\mathrm{HFD}$ 그룹 및 $\mathrm{LFD}$ 그룹으로 나타났다. 이 는 $\mathrm{LFD}$ 그룹과 $\mathrm{HFD}$ 그룹이 서로 미생물 생태는 다르게 나타나 지만, 각각 $\mathrm{CTL}$ 그룹과 비교하였을 때 보다는 비슷한 미생물 군 집으로 존재하는 것으로 판단된다. $\mathrm{NMDS}$ 에서 각 점들은 각 실 험동물 개체별 장내 미생물 생태를 나타내고 점 간 사이의 거 리가 가까울수록 장내 미생물 생태는 비슷하다는 것을 나타낸 다. 각 그룹은 유의적으로 서로 다른 군집을 나타났다 $(p<0.001)$. 좌표 상의 화살표(correlation arrows)는 각 그룹에서 유의적으로 관련이 있는 genus 수준의 미생물을 뜻하는데, 이는 각 그룹에 서 상대적으로 많이 존재하는 미생물이면서 유의적으로 연관된 군집일수록 해당 방향과 길이로 나타난다 $(p<0.05)$. Sutterella, Erysipelotrichaceae_unclassified, Roseburia는 CTL 그룹보다 $\mathrm{LFD}$ 그룹 및 $\mathrm{HFD}$ 그룹에서 상대적으로 증가함을 나타내며, 그 중 화살표의 방향성으로 판단하였을 때 $\mathrm{HFD}$ 그룹보다 LFD그룹 과 더 연관이 있는 것으로 사료된다. 한편, CTL그룹에서는 Butyricicoccus 와 Clostridium (Lachnospiraceae family)이 LFD 그룹 및 $\mathrm{HFD}$ 그룹보다 더 많이 상대적으로 많이 존재함을 나 타낸다 $(p<0.05)$.

Phylum 수준에서 각 그룹 내 실험동물 개체별 계통수 비교 는 Fig. 2 (C)에 나타내었고, 세 그룹 간의 장내미생물생태는 크게 세 가지 Phylum 수준에서 차이가 나타나는 것을 확인할 수 있었다. 먼저, Proteobacteria의 분포는 LFD그룹과 HFD그룹 에서 유의적으로 증가하며 $(p<0.05)$, 이는 비만 환자에게서 높은 비율로 나타난다고 보고되어 있으며[24], 또한 염증성장질환 (IBD)과 밀접하게 관련되어 있는 미생물이라고 보고되어있다 [25]. Bacteroidetes의 분포는 LFD 그룹에서 CTL 그룹보다 유 의적인 감소는 나타나지 않았으나, $\mathrm{HFD}$ 그룹은 $\mathrm{CTL}$ 그룹과 비교하여 유의적으로 감소함을 나타내었다 $(p<0.05)$. Firmicutes 의 분포는 $\mathrm{CTL}$ 그룹과 $\mathrm{HFD}$ 그룹, $\mathrm{CTL}$ 그룹과 $\mathrm{LFD}$ 그룹 사 이에서는 차이가 나타나지 않았으나, $\mathrm{HFD}$ 그룹과 $\mathrm{LFD}$ 그룹사 이의 비교 분석에서는 $\mathrm{HFD}$ 에서 유의적으로 증가함을 확인되었
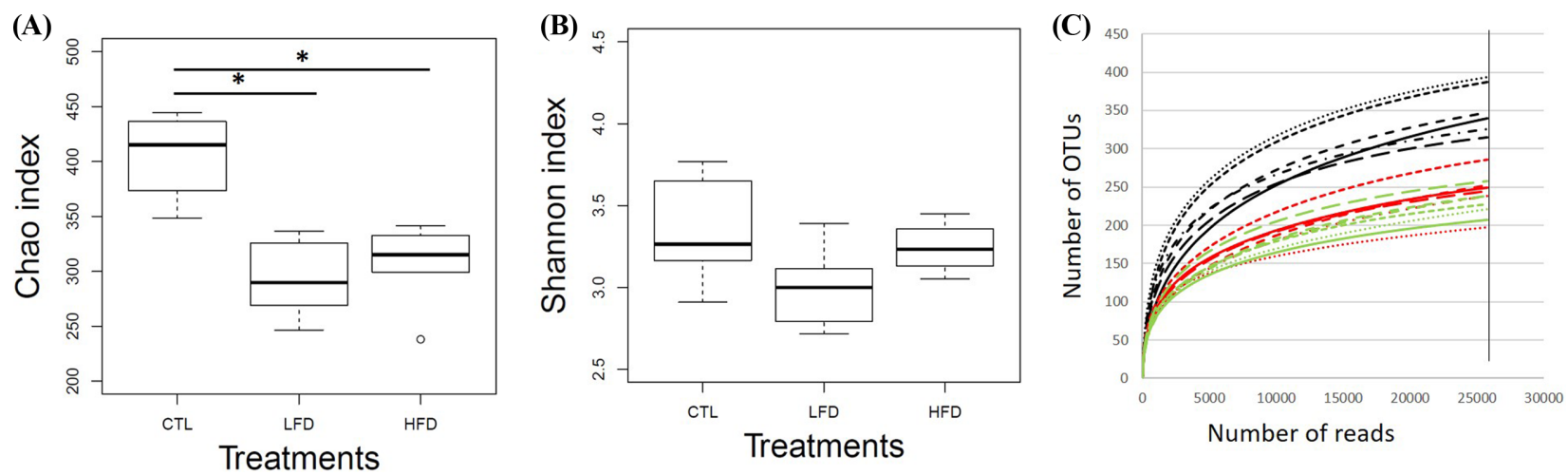

Fig. 1 Comparison of diversity index and rarefaction curve on each treatment. ${ }^{*} p<0.001$ vs CTL group in Tukey's HSD test. All sample in (C) was subsampled by 25763 reads. Colors of curve indicate CTL (black), LFD (green) and HFD (red) group, respectively. Each type of line indicates individual mouse in each treatment 

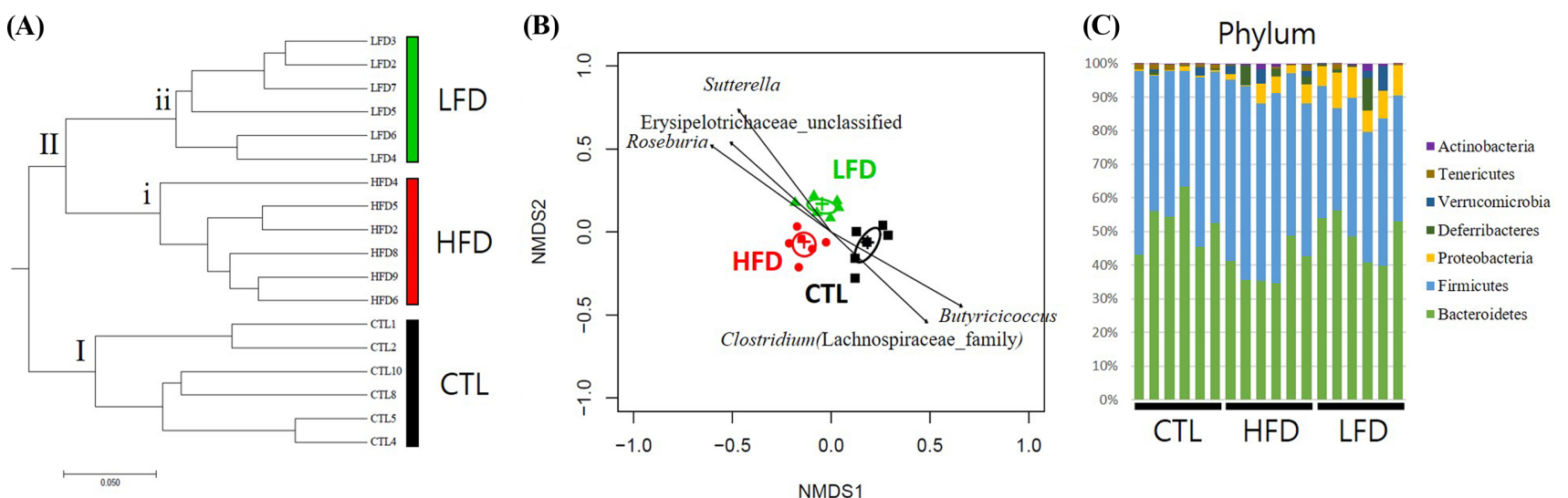

Fig. 2 The shifts of gut microbiota of mice by high fat and low fiber diet: Phylogenic tree (A), gut microbiota on NMDS (B), and taxonomic composition in phylum level (C)

다 $(p<0.05)$.

미시적인 장내미생물생태 비교는 METASTATS를 이용하여 genus 수준에서 CTL:LFD, CTL:HFD, LFD:HFD 일대일비교 하여 유의적인 차이가 나타나는 것들 중 전체 reads에 $1 \%$ 이 상 차지하는 OTU만을 선정하여 heatmap으로 나타내었고(Fig. 3 ), 이에 대한 각 그룹 내 genus의 비율은 Table S1에 나타내 었다.

$\mathrm{CTL}$ 그룹에 비하여 $\mathrm{LFD}$ 그룹과 $\mathrm{HFD}$ 그룹에서 공통적으로 증가한 genus은 Sutterella, Ruminococcaceae_unclassified, [Mogibacteriaceae]_unclassified, Clostridium (Erysipelotrichaceae family), Parabacteroides, [Ruminococcus] (Lachnospiraceae family), $r c 4$-4 로 확인되었다 $(p<0.05)$. 이 중 가장 높은 비율을 차지하 는 것은 Sutterella (Proteobacteria phylum)로, 이는 correlation arrow에서도 나타났으며(Fig. 2-B), CTL, LFD, HFD 그룹에서 각각 $0.08 \pm 0.02,6.98 \pm 0.68,3.32 \pm 0.94 \%$ 의 비율로 분포하였다. 이는 자폐증 스팩트럼 장애를 않고 있으며 동시에 소화관 장애 가 있는 아동에게서 높은 비율이 나타난 결과가 보고되어 있다 [26]. Proteobacteria phylum내에 또다른 genus인 [Ruminococcus] 는 $\mathrm{LFD}$ 그룹과 $\mathrm{HFD}$ 그룹에서 유의적으로 증가하였고 $(p<0.05)$, 각각 $1.57 \pm 0.45,1.42 \pm 0.11 \%$ 를 차지하고 있으며, CTL 그룹은 $0.34 \pm 0.06 \%$ 로 확인되었다. 이는 뮤신을 분해하여 단쇄지방산을 생성하는 것으로 알려져 있으며, species에 따라 다른 것으로 보 고되어있다[27]. 한편, Ruminococcaceae (Firmicutes phylum)는 $\mathrm{HFD}$ 그룹에서 $4.92 \pm 0.90 \%$ 의 비율을 차지하고 있으며, $\mathrm{CTL}$ 그 룹과 $\mathrm{LFD}$ 그룹에서는 각각 $1.07 \pm 0.12,1.73 \pm 0.22 \%$ 로 확인되었 다. Ruminococcacea family는 고지방 식이를 먹인 쥐에게서 증 가한다고 보고되어 있으며[28], butyric acid 생성 경로와 연관 되어있다고 보고되어있다[29]. 또한 이는 탄수화물-활성 효소 (Carbohydrate-active enzyme) 및 당 운반 대사에 관여하는 장 내 미생물이라는 연구가 되어있다[30]. Clostridium은 Erysipelotrichaceae family의 하나로, LFD 그룹과 HFD 그룹에서 각각 $5.43 \pm 0.54,1.94 \pm 0.28 \%$ 의 비율로 분포하며, $\mathrm{CTL}$ 그룹에서는 $0.15 \pm 0.03 \%$ 를 차지하고 있었다. C.cocleatum은 병원성미생물인 C.difficille생성을 억제하며, 뮤신층을 분해하는 것으로 보고되어 있다[31]. 한편 Parabacteroides (Bacteoidetes phylum)는 HIV 와 연관되어 있는데[32], $\mathrm{HFD}$ 그룹과 $\mathrm{LFD}$ 그룹에서 각각
$3.86 \pm 1.16,2.03 \pm 0.26 \%$ 로, CTL 그룹에서는 $0.90 \pm 0.12 \%$ 의 비율 로 확인되었다. Firmicutes에 속하는 Erysipelotrichaceae family 는 고지방 식이로 유도되어진 비만 쥐에게서 높은 비율로 존재 하며[33], 직장암 환자에게서 발견이 되어지고 있고[34], HIV질 환과도 연관되어 있다는 연구가 보고되어 있다[32].

$\mathrm{CTL}$ 그룹에 비하여 $\mathrm{LFD}$ 그룹과 $\mathrm{HFD}$ 그룹에서 공통적으로 감소한 genus은 S24-7_unclassified, Clostridiales_unclassified, Clostridium (Lachnospiraceae family), Lactobacillus로 확인되었 고 $(p<0.05)$, 이 중 가장 많이 감소한 genus은 S24-7_unclassified 로, $\mathrm{LFD}$ 그룹과 $\mathrm{HFD}$ 그룹에서 각각 $11.81 \pm 1.26,7.38 \pm 2.29 \%$ 의 비율을 차지하였으며, CTL 그룹에서는 $19.5 \pm 2.65 \%$ 의 비율 로 나타났다. S24_7 family는 생쥐 장내에서 우세한 군집으로 알려져 있고[35], 비만 쥐와 비교하여 비만이 아닌 쥐에게서 높 은 비율로 발견된다고 연구되어져 있으며[36], 고지방사료 섭취 에 의해서 비만이 유도된 쥐에게 운동을 시켰을 경우 증가하는 양상을 보인다고 알려져 있다[37]. 또한 S24_7 family는 단쇄지 방산 중 하나인 butyric acid을 생성하는 균으로 보고가 되어있 어 있다[38]. 이러한 연구결과에 따라 본 연구에서 나타난 LFD 그룹에서 S24-7 family의 감소는 장 기능을 저하시키고 체내 비 만 유도 기작과 관련성이 있을 것이라 판단되어진다. Clostridium (Lachnospiraceae family)는 LFD 그룹과 HFD 그룹에서 감소하 였는데, 특히 Clostridium cluster XIVa는 장내에 butyric acid 을 생성하고[39], 크론병 환자에게서 낮은 비율로 존재한다는 연구가 보고 되어있다[40]. Clostridium cluster XIVa 비율은 장 내미생물생태의 생태를 확인하는 척도로 사용되어지고 있으며, $\mathrm{IBD}$ 환자의 장 기능 저하 여부를 판단할 때 사용되고 있다[40]. 이에 LFD그룹와 HFD 그룹에서 Clostridium (Lachnospiraceae family)가 감소하는 양상을 나타내는 것은 각각 고지방과 저식 이섬유 식이로 인해 장기능이 저하되어 나타나는 결과로 판단 된다. Lactobacillus는 CTL그룹에서 $9.20 \pm 1.78 \%, \mathrm{LFD}$ 그룹에 서는 $1.38 \pm 0.29 \%, \mathrm{HFD}$ 그룹에서는 $1.07 \pm 0.56 \%$ 의 비율을 차지 하는 것으로 확인되었다. Lactobacillus는 대표적인 프로바이오 틱 균주로 장내에서 단쇄지방산의 생성을 유도하여 장내 염증 을 감소시킨다고 연구되어 있다[41,42].

LFD그룹에서만 증가한 genus은 Coprococcus, Erysipelotrichaceae unclassified, RF32_unclassified이며, 반대로 감소한 genus는 

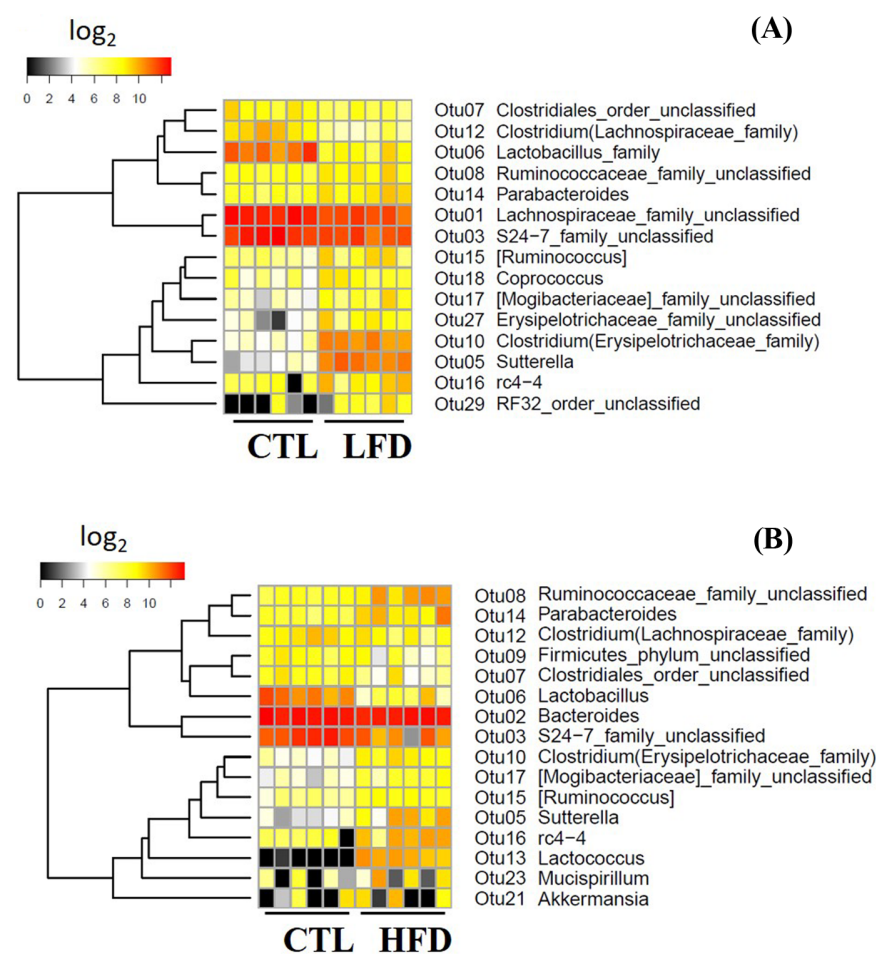

Lachnospiraceae unclassified으로 나타났다 $(p<0.05)$. Coprococcus 는 자폐성 장애아동에서 나타나고[43], IBD 환자에게서 낮은 비 율로 나타나며, butyric acid를 생성하는 것으로 알려져 있다 [44]. 또한 butyric acid으로부터 propionic acid를 생성하는 경 로와 연관되어 있는 장내 미생물이라고 보고되어 있다[45]. 한 편 Lachnospiraceae family는 다당류를 분해하여 단쇄지방산을 생성하는 미생물로 알려져 있으며[46], IBD 환자의 장내에서 감 소하며, 비만인 사람의 장내애서는 증가한다고 알려져 있다[47]. 이들 Lachnospiraceae_unclassified는 LFD그룹에서 다른 두 그 룹에 비해 감소함을 나타내었으며, 이는 식이섬유가 부족한 식 이를 섭취한 그룹에서 Lachnospiraceae family의 분포가 줄어들 어 단쇄지방산의 감소를 유발하여 장 기능을 저해 시킬 것이라 고 판단된다.

$\mathrm{HFD}$ 그룹에서만 증가한 genus은Lactococcus, Akkermansia, Mucispirillum 이며, 감소한 genus은 Bacteroides, Firmicutes unclassified이다( $\mathrm{p}<0.05)$. Lactococcus는 HFD그룹에서 $4.79 \pm 0.58 \%$ 의 비율을 차지하였으며, CTL그룹에서는 나타나지 않았고, LFD 그룹에서는 $0.01 \pm 0 \%$ 의 비율로 확인되었다. Lactococcus는 Firmicutes phylum에 속하며, 고지방 식이로 인해 비만이 유도 된 쥐에게서 증가하는 연구가 보고되어 있다[48]. 한편 Bacteroides는 $\mathrm{HDF}$ 그룹에서 $28.44 \pm 1.4 \%$ 의 비율로 나타났으며 $\mathrm{CTL}$ 그룹과 $\mathrm{LFD}$ 그룹에서는 각각 $28.44 \pm 1.4,34.86 \pm 2.61 \%$ 비율 을 차지하는 것으로 확인되었다. 이는 Bacteroides가 고지방 식 이 유발 비만 모델 및 $\mathrm{ob} / \mathrm{ob}$ 유전성 비만 동물 모델에서 감소한 다는 연구와 비슷한 결과를 나타내었다 [49].

$16 \mathrm{~S} \mathrm{rRNA}$ 유전자 기반 물질대사 경로 추정은 $p<0.05$ 일 때 유의성이 있는 것으로 판단하였고, $p<0.01$ 인 것을 heatmap으로 나타내었으며(Fig. S1), 그 중 유의적으로 같은 양상을 보이고 abundance가 높은 무리인 I 를 Table 3에 나타내었다. LFD그룹

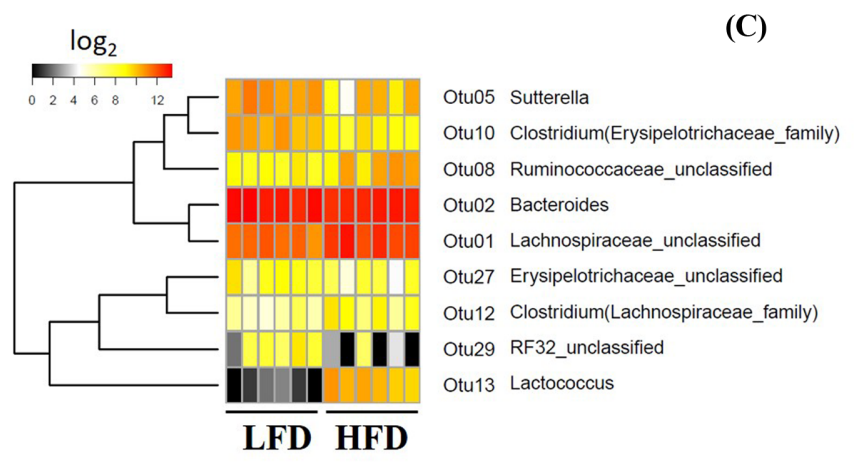

Fig. 3 Heatmap profile showing the relative abundance of phylotype between each treatment microbiota: (A) CTL:LFD, (B) CTL:HFD, (C) LFD:HFD group

에서는 에너지대사과정 관련 경로에서 메탄대사 관련 미생물을 제외하고 모두 유의적으로 증가하였으나 $(p<0.01)$, 아미노산대사 과정 및 탄수화물대사 과정에 관여하는 미생물의 수는 유의적 으로 감소함을 나타내었다 $(p<0.05)$. HFD그룹에서는 CTL그룹 과 비교하여 탄수화물 대사와 관련이 있는 미생물의 수에 있어 서 유의적인 차이가 나타나지 않았으나, $\mathrm{LFD}$ 그룹에서는 감소 하는 양상이 확인되었다(Table 3). 이러한 대사과정에 관련된 미 생물의 차이는 저식이섬유 섭취로 인한 장내 미생물 다양성 감 소로 인한 결과로 사료된다. 사료에 식이섬유를 함유량을 다르 게 하여 사육한 돼지의 메탄가스 생성량과 미생물 다양성을 분 석한 논문에서 저식이섬유를 섭취한 돼지의 경우 고식이섬유 함 유를 섭취한 돼지에 비해서 대장 내 에서의 미생물 다양성 감 소와 함께 장내 미생물이 에너지 대사과정에 생성되는 부산물 인 메탄가스 생성도 감소한다고 보고되어 있다[50]. 또한, 저식 이섬유를 섭취한 돼지의 장내 미생물에서 식이섬유를 분해하는 미생물의 수는 고식이섬유를 함유한 돼지보다 감소함을 나타낸 다고 보고되어있다[51]. 다양한 장내 미생물 그룹에서 Bacteriodetes phylum은 에너지 대사에 중요한 역할을 하는 미 생물들이라고 알려져 있으며, 특히 장내에서 식이섬유 분해과정 에서 중요한 역할을 한다고 알려져 있다[52]. LFD 그룹에서 탄 수화물대사 과정에 관여하는 미생물의 수의 감소는 Bacteriodetes phylum의 감소로 인한 결과로 추정된다. 또한 Ruminococcaceae family와 같은 미생물 그룹은 탄수화물 활성 효소와 당 운반 대 사와 연관된 효소들의 활성 관여하며 이러한 Ruminococcaceae family 증가에 의해서 LFD 그룹에 에너지 대사 관련 유전자들 이 증가하는 것으로 생각된다. $\mathrm{HFD}$ 그룹에서는 아미노산 대사 에 관여하는 미생물의 수가 유의적으로 증가하였는데 $(p<0.05)$, 티로신 생합성은 비만환자에게서 증가하며[53], 페닐알라닌 생 합성은 alkaline phosphate (IAP)의 활성을 억제시켜 비만, 당뇨, 
Table 3 Comparison of relative metabolic pathway between each treatment

\begin{tabular}{|c|c|c|c|c|c|}
\hline & \multirow{2}{*}{ KEGG Description } & \multicolumn{2}{|c|}{ CTL vs } & \multicolumn{2}{|c|}{ LFD vs HFD } \\
\hline & & LFD & HFD & LFD & HFD \\
\hline \multirow{3}{*}{ Amino Acid Metabolism } & Arginine and proline metabolism & $\downarrow * *$ & - & $\downarrow * * *$ & \\
\hline & Cysteine and methionine metabolism & - & $\uparrow *$ & & $\uparrow * *$ \\
\hline & Phenylalanine, tyrosine and tryptophan biosynthesis & - & $\uparrow * *$ & - & - \\
\hline \multirow{4}{*}{ Carbohydrate Metabolism } & Amino sugar and nucleotide sugar metabolism & $\downarrow * *$ & - & $\downarrow *$ & \\
\hline & Fructose and mannose metabolism & $\downarrow * * *$ & - & $\downarrow * *$ & \\
\hline & Pyruvate metabolism & $\downarrow *$ & - & $\downarrow * *$ & \\
\hline & Starch and sucrose metabolism & $\downarrow * * *$ & - & $\downarrow * *$ & \\
\hline \multirow{3}{*}{ Energy Metabolism } & Methane metabolism & $\downarrow * *$ & - & $\downarrow * * *$ & \\
\hline & Oxidative phosphorylation & $\uparrow * *$ & - & $\uparrow * *$ & \\
\hline & Carbon fixation pathways in prokaryotes & $\uparrow * * *$ & - & $\uparrow * *$ & \\
\hline $\begin{array}{c}\text { Glycan Biosynthesis and } \\
\text { Metabolism }\end{array}$ & Peptidoglycan biosynthesis & $\uparrow * *$ & $\uparrow * *$ & - & - \\
\hline
\end{tabular}

-: not significant; ${ }^{*} p<0.05,{ }^{* *} p<0.01,{ }^{* *} p<0.001$ in Tukey's HSD test; Arrows mean increase or decrease compare to other treatment

대사 증후군을 유발할 수 있다는 연구가 보고되어 있다[54]. 글 리칸 생합성 및 대사 과정에 관여하는 미생물은LFD그룹 및 $\mathrm{HFD}$ 그룹 모두 유의적으로 증가하였는데 $(p<0.01)$, 최근 연구 에 따르면 식이 내 식이섬유를 비롯한 글리칸 조성이 부족 하 면 Akkermansia 및 Mucinospirllium 과 같은 장 상피세포의 뮤 신층 존재하는 글리칸을 분해하는 장내 특정미생물들이 증가하 여 숙주의 장 기능에 이상을 유발하기도 한다고 연구되어있다 [55]. 또 다른 연구에 따르면, 식이 내 식이섬유가 없을 시 장 상피세포의 뮤신층을 에너지원으로 사용하는 뮤신층-분해 미생 물 수는 증가하며, 이는 뮤신층 분해와 연관된 Carbohydrate active enzymes (CAZymes)의 발현양을 증가시켜 뮤신층의 분 해를 일으키고, 이로 인해 소화기 내 병원성미생물의 민감성은 증가한다고 보고되어있다[56]. 본 연구에서는 저식이섬유 및 고 지방 식이 공급으로 인하여 Akkermansia 및 Mucinospirllium과 같은 장내 미생물들이 증가하여 성장에 필요한 에너지원을 얻 기 위하여 장 상피세포에 존재하는 뮤신층의 글리칸을 분해를 하여 얻어진 당질을 이용하여 미생물 생장에 이용하였을 것으 로 판단된다.

\section{초 록}

경제발전으로 인해 한국인의 식습관이 점차 서구화됨에 따라 웰 빙(Well-being)의 문제가 야기되고 있다. 웰빙은 장내 미생물 군 집과 밀접하게 연관되어 있으며, 이는 섭취한 음식에 따라 가 변적이다. 이에 본 연구에서는 장내 미생물의 $16 \mathrm{~S} \mathrm{rRNA}$ 유전 자를 기반으로 하여 $\mathrm{MiSeq}$ 을 진행하였고, 고지방 식이(HFD) 및 저식이섬유 식이(LFD)로 인한 장내의 미생물 생태 비교 및 분석하고자 수행되었다. 일반 대조군(CTL) 그룹과 비교하여 각 각 $\mathrm{LFD}$ 그룹과 $\mathrm{HFD}$ 그룹은 species richness가 유의적으로 감 소하였고, species evenness에서는 차이가 나타나지 않았다. phylum 수준에서는 Proteobacteria는 두 처리군에서 유의적으로 증가하였고 $(p<0.05)$, 그 중 Sutterella genus가 유의적으로 가장 많이 증가하였다. Bacteroidetes는 HFD 그룹에서 유의적으로 감
소하였고, S24-7 family가 가장 큰 비율로 감소하였다. 한편 Firmicutes는 HFD:LFD 그룹에서 차이를 보였고, LFD 그룹에 서 Lachnospiraceae family가 유의적으로 낮은 비율로 나타난 것이 확인되었다 $(p<0.05)$. PICUSt 기반 신진대사 분석에서 $\mathrm{LFD}$ 그룹은 아미노산 대사 및 탄수화물 대사에 관여하는 미생 물 수가 유의적으로 감소하는 양상을 보였고 $(p<0.05)$, 에너지 대사에서는 메탄 대사에 관여하는 미생물이 유의적으로 감소하 였다 $(p<0.01)$. 한편 $\mathrm{HFD}$ 그룹에서는 아미노산 대사에 관여하 는 미생물 수가 유의적으로 증가하였다 $(p<0.05)$. 글리칸 생합성 및 대사에 관여하는 미생물은 $\mathrm{LFD}$ 그룹과 $\mathrm{HFD}$ 그룹에서 유 의적으로 증가하는 것으로 나타났다 $(p<0.01)$. 이상의 결과를 통 해 지속적으로 불균형한 식단을 섭취하는 것은 장내 환경을 dysbiosis시켜, 대사성 질환 및 장 기능 저하를 유발할 것으로 예상된다.

Keywords Gut microbiome $\cdot$ High-fat diet $\cdot$ Low-fiber diet

감사의 글 이 논문은 2017 학년도 제주대학교 교원성과지원사업에 의하여 연구되었으며 이에 감사를 드립니다.

\section{References}

1. Koo S, Park K (2013) Dietary behaviors and lifestyle characteristics related to frequent eating out among Korean adults. J Korean Soc Food Sci Nutr 42: 705-712

2. Choi, Tae H, Hong, Ki W (2015) A study on dining out and dietary behavioral pattern according to gender of university students. The study of foodservice industry and management 11: 31-50

3. Chooi YL (2013) The Effect of High-Fat Diet-Induced Pathophysiological Changes in the Gut on Obesity: What Should be the Ideal Treatment? Clin Transl Gastroenterol 4: e39

4. Van Dam RM, Willett WC, Rimm EB, Stampfer MJ, Hu FB (2002) Dietary fat and meat intake in relation to risk of type 2 diabetes in men. Diabetes Care 25, 417-424

5. Roza NaV, Possignolo LF, Palanch AC, Gontijo JaR (2016) Effect of long-term high-fat diet intake on peripheral insulin sensibility, blood 
pressure, and renal function in female rats. Food \& Nutrition Research 60, 10.3402/fnr.v60.28536

6. Bruder-Nascimento T, Ekeledo OJ, Anderson R, Le HB, Belin De Chantemèle EJ (2017) Long Term High Fat Diet Treatment: An Appropriate Approach to Study the Sex-Specificity of the Autonomic and Cardiovascular Responses to Obesity in Mice. Frontiers in Physiology 8: 32

7. Calligaris SD, Lecanda M, Solis F, Ezquer M, Gutierrez J, Brandan E, Leiva A, Sobrevia L, Conget P (2013) Mice long-term high-fat diet feeding recapitulates human cardiovascular alterations: an animal model to study the early phases of diabetic cardiomyopathy. PLoS One 8 : e60931

8. Grooms KN, Ommerborn MJ, Pham DQ, Djoussé L, Clark CR (2013) Dietary Fiber Intake and Cardiometabolic Risks among US Adults, NHANES 1999-2010. The American Journal of Medicine 126: 10591067. e1-4

9. Farvid MS, Eliassen AH, Cho E, Liao X, Chen WY, Willett WC (2016) Dietary Fiber Intake in Young Adults and Breast Cancer Risk. Pediatrics: e20151226.

10. Singh S, Dulai PS, Zarrinpar A, Ramamoorthy S, Sandborn WJ (2017) Obesity in IBD: epidemiology, pathogenesis, disease course and treatment outcomes. Nat Rev Gastroenterol Hepatol 14, 110-121

11. Xu J, Mahowald MA, Ley RE, Lozupone CA, Hamady M, Martens EC, Henrissat B, Coutinho PM, Minx P, Latreille P, Cordum H, Van Brunt A, Kim K, Fulton RS, Fulton LA, Clifton SW, Wilson RK, Knight RD, Gordon JI (2007) Evolution of symbiotic bacteria in the distal human intestine. PLoS Biol 5, e156

12. Gill SR, Pop M, Deboy RT, Eckburg PB, Turnbaugh PJ, Samuel BS, Gordon JI, Relman DA, Fraser-Liggett CM, Nelson KE (2006) Metagenomic analysis of the human distal gut microbiome. Science 312: $1355-1359$

13. Krajmalnik-Brown R, Ilhan ZE, Kang DW, Dibaise JK (2012) Effects of gut microbes on nutrient absorption and energy regulation. Nutr Clin Pract 27, 201-214

14. Kinross JM, Darzi AW, Nicholson JK (2011) Gut microbiome-host interactions in health and disease. Genome Med 3: 14

15. Carding S, Verbeke K, Vipond DT, Corfe BM, Owen LJ (2015) Dysbiosis of the gut microbiota in disease. Microb Ecol Health Dis 26: 26191

16. Sonnenburg JL, Xu J, Leip DD, Chen CH, Westover BP, Weatherford J, Buhler JD, Gordon JI (2005) Glycan foraging in vivo by an intestineadapted bacterial symbiont. Science 307, 1955-1959

17. Bäckhed F, Ding H, Wang T, Hooper LV, Koh GY, Nagy A, Semenkovich CF, Gordon JI (2004) The gut microbiota as an environmental factor that regulates fat storage. Proceedings of the National Academy of Sciences of the United States of America 101: 15718-15723

18. Perry RJ, Peng L, Barry NA, Cline GW, Zhang D, Cardone RL, Petersen KF, Kibbey RG, Goodman AL, Shulman GI (2016) Acetate mediates a microbiome-brain-beta-cell axis to promote metabolic syndrome. Nature 534, 213-217

19. Roewer L, Kayser M, Dieltjes P, Nagy M, Bakker E, Krawczak M, de Knijff P (1996) Analysis of molecular variance (AMOVA) of Ychromosome-specific microsatellites in two closely related human populations. Hum Mol Genet 5, 1029-1033

20. White JR, Nagarajan N, Pop M (2009) Statistical methods for detecting differentially abundant features in clinical metagenomic samples. PLoS Comput Biol 5, e1000352

21. Langille MGI, Zaneveld J, Caporaso JG, McDonald D, Knights D, Reyes JA, Clemente JC, Burkepile DE, Vega Thurber RL, Knight R, Beiko RG Huttenhower C (2013) Predictive functional profiling of microbial communities using 16S rRNA marker gene sequences. Nat Biotechnol 31, 814-821

22. Parks DH, Beiko RG (2010) Identifying biologically relevant differences between metagenomic communities. Bioinformatics 26, 715-721
23. Morris EK, Caruso T, Buscot F, Fischer M, Hancock C, Maier TS, Meiners T, Muller C, Obermaier E, Prati D, Socher SA, Sonnemann I, Waschke N, Wubet T, Wurst S, Rillig MC (2014) Choosing and using diversity indices: insights for ecological applications from the German Biodiversity Exploratories. Ecol Evol 4, 3514-3524

24. Hildebrandt MA, Hoffmann C, Sherrill-Mix SA, Keilbaugh SA, Hamady M, Chen YY, Knight R, Ahima RS, Bushman F, Wu GD (2009) High-fat diet determines the composition of the murine gut microbiome independently of obesity. Gastroenterology 137: 1716-1724 e1-2

25. Mukhopadhya I, Hansen R, El-Omar EM, Hold GL (2012) IBD-what role do Proteobacteria play? Nat Rev Gastroenterol Hepatol 9, 219-230

26. Balzola F, Cullen G, Ho GT, Russell RK, Wehkamp J (2012) Application of novel PCR-based methods for detection, quantitation, and phylogenetic characterization of Sutterella species in intestinal biopsy samples from children with autism and gastrointestinal disturbances

27. Hoskins LC (1993) Mucin degradation in the human gastrointestinal tract and its significance to enteric microbial ecology. European Journal of Gastroenterology \& Hepatology 5: 205-213

28. Bruce-Keller AJ, Salbaum JM, Luo M, Blanchard Et, Taylor CM, Welsh DA, Berthoud HR (2015) Obese-type gut microbiota induce neurobehavioral changes in the absence of obesity. Biol Psychiatry 77, $607-615$

29. Duncan SH, Louis P, Flint HJ (2004) Lactate-utilizing bacteria, isolated from human feces, that produce butyrate as a major fermentation product. Appl Environ Microbiol 70: 5810-5817

30. Biddle A, Stewart L, Blanchard J, Leschine S (2013) Untangling the Genetic Basis of Fibrolytic Specialization by Lachnospiraceae and Ruminococcaceae in Diverse Gut Communities. Diversity 5: 627

31. Boureau H, Decre D, Carlier JP, Guichet C, Bourlioux P (1993) Identification of a Clostridium cocleatum strain involved in an antiClostridium difficile barrier effect and determination of its mucindegrading enzymes. Res Microbiol 144: 405-410

32. Vujkovic-Cvijin I, Dunham RM, Iwai S, Maher MC, Albright RG, Broadhurst MJ, Hernandez RD, Lederman MM, Huang Y, Somsouk M, Deeks SG, Hunt PW, Lynch SV, McCune JM (2013) Dysbiosis of the gut microbiota is associated with HIV disease progression and tryptophan catabolism. Sci Transl Med 5, 193ra91

33. Turnbaugh PJ, Backhed F, Fulton L, Gordon JI (2008) Diet-induced obesity is linked to marked but reversible alterations in the mouse distal gut microbiome. Cell Host Microbe 3, 213-223

34. Chen W, Liu F, Ling Z, Tong X, Xiang C (2012) Human intestinal lumen and mucosa-associated microbiota in patients with colorectal cancer. PLoS One 7: e39743

35. Seedorf H, Griffin NW, Ridaura VK, Reyes A, Cheng J, Rey FE, Smith MI, Simon GM, Scheffrahn RH, Woebken D, Spormann AM, Van Treuren W, Ursell LK, Pirrung M, Robbins-Pianka A, Cantarel BL, Lombard V, Henrissat B, Knight R, Gordon JI (2014) Bacteria from diverse habitats colonize and compete in the mouse gut. Cell 159, 253266

36. Turnbaugh PJ, Ley RE, Mahowald MA, Magrini V, Mardis ER, Gordon JI (2006) An obesity-associated gut microbiome with increased capacity for energy harvest. Nature 444, 1027-1031

37. Evans CC, LePard KJ, Kwak JW, Stancukas MC, Laskowski S, Dougherty J, Moulton L, Glawe A, Wang Y, Leone V, Antonopoulos DA, Smith D, Chang EB, Ciancio MJ (2014) Exercise prevents weight gain and alters the gut microbiota in a mouse model of high fat dietinduced obesity. PLoS One 9: e92193

38. Liu H-X, Rocha CS, Dandekar S, Yvonne Wan Y-J (2016) Functional analysis of the relationship between intestinal microbiota and the expression of hepatic genes and pathways during the course of liver regeneration. Journal of Hepatology 64, 641-650

39. Pryde SE, Duncan SH, Hold GL, Stewart CS, Flint HJ (2002) The microbiology of butyrate formation in the human colon. FEMS Microbiol Lett 217, 133-139

40. Kabeerdoss J, Jayakanthan P, Pugazhendhi S, Ramakrishna BS (2015) 
Alterations of mucosal microbiota in the colon of patients with inflammatory bowel disease revealed by real time polymerase chain reaction amplification of $16 \mathrm{~S}$ ribosomal ribonucleic acid. Indian $\mathrm{J}$ Med Res 142: 23-32

41. Liu Y, Fatheree NY, Mangalat N, Rhoads JM (2010) Human-derived probiotic Lactobacillus reuteri strains differentially reduce intestinal inflammation. Am J Physiol Gastrointest Liver Physiol 299, G10871096

42. Masood MI, Qadir MI, Shirazi JH, Khan IU (2011) Beneficial effects of lactic acid bacteria on human beings. Crit Rev Microbiol 37, 91-98

43. Song Y, Liu C, Finegold SM (2004) Real-time PCR quantitation of clostridia in feces of autistic children. Appl Environ Microbiol 70, 64596465

44. Louis P, Flint HJ (2009) Diversity, metabolism and microbial ecology of butyrate-producing bacteria from the human large intestine. FEMS Microbiol Lett 294, 1-8

45. Flint HJ, Duncan SH, Scott KP, Louis P (2015) Links between diet, gut microbiota composition and gut metabolism. Proc Nutr Soc 74: 13-22

46. Frank DN, St Amand AL, Feldman RA, Boedeker EC, Harpaz N, Pace NR (2007) Molecular-phylogenetic characterization of microbial community imbalances in human inflammatory bowel diseases. Proc Natl Acad Sci U S A 104: 13780-13785

47. Meehan CJ, Beiko RG (2014) A phylogenomic view of ecological specialization in the Lachnospiraceae, a family of digestive tractassociated bacteria. Genome Biol Evol 6, 703-713

48. Zhang C, Zhang M, Pang X, Zhao Y, Wang L, Zhao L (2012) Structural resilience of the gut microbiota in adult mice under high-fat dietary perturbations. ISME J 6, 1848-1857

49. Murphy EF, Cotter PD, Healy S, Marques TM, O'Sullivan O, Fouhy F, Clarke SF, O'Toole PW, Quigley EM, Stanton C, Ross PR, O'Doherty RM, Shanahan F (2010) Composition and energy harvesting capacity of the gut microbiota: relationship to diet, obesity and time in mouse models. Gut 59, 1635-1642

50. Jensen BB, Jorgensen H (1994) Effect of dietary fiber on microbial activity and microbial gas production in various regions of the gastrointestinal tract of pigs. Appl Environ Microbiol 60: 1897-1904

51. Heinritz SN, Weiss E, Eklund M, Aumiller T, Louis S, Rings A, Messner S, Camarinha-Silva A, Seifert J, Bischoff SC, Mosenthin R (2016) Intestinal Microbiota and Microbial Metabolites Are Changed in a Pig Model Fed a High-Fat/Low-Fiber or a Low-Fat/High-Fiber Diet. PLoS One 11: e0154329

52. Flint HJ, Scott KP, Duncan SH, Louis P, Forano E (2012) Microbial degradation of complex carbohydrates in the gut. Gut Microbes 3: 289306

53. Adams SH (2011) Emerging perspectives on essential amino acid metabolism in obesity and the insulin-resistant state. Adv Nutr 2: 445456

54. Gul SS, Hamilton AR, Munoz AR, Phupitakphol T, Liu W, Hyoju SK, Economopoulos KP, Morrison S, Hu D, Zhang W, Gharedaghi MH, Huo H, Hamarneh SR, Hodin RA (2017) Inhibition of the gut enzyme intestinal alkaline phosphatase may explain how aspartame promotes glucose intolerance and obesity in mice. Appl Physiol Nutr Metab 42: $77-83$

55. Koropatkin NM, Cameron EA, Martens EC (2012) How glycan metabolism shapes the human gut microbiota. Nat Rev Microbiol 10, 323-335

56. Desai MS, Seekatz AM, Koropatkin NM, Kamada N, Hickey CA, Wolter M, Pudlo NA, Kitamoto S, Terrapon N, Muller A, Young VB, Henrissat B, Wilmes P, Stappenbeck TS, Nunez G, Martens EC (2016) A Dietary Fiber-Deprived Gut Microbiota Degrades the Colonic Mucus Barrier and Enhances Pathogen Susceptibility. Cell 167: 1339-1353 e21 